Tatiana KRYNICKA*

\title{
WCZESNA KORESPONDENCJA AUZONIUSZA Z PAULINEM Z NOLI
}

Paulin z Noli był wychowankiem, uczniem, wielbicielem talentu i bliskim przyjacielem Auzoniusza. Gdy po przyjęciu chrztu ok. 390 r. całkowicie poświęcił się życiu ascetycznemu, porzucił dotychczasową twórczość literacką oraz zerwał stosunki z mistrzem ${ }^{1}$. Badacze poświęcają wiele uwagi listom Burdigalczyka, w których wyraża on głęboki żal z powodu zaistniałej sytuacji (Listy 21-24)2, a także odpowiedziom broniącego się przed jego wyrzutami Paulina ${ }^{3}$ (Pieśni 10-11) ${ }^{4}$. Tymczasem zdecydowanie mniej znane są listy Auzoniusza do wychowanka z wcześniejszego okresu (383-389) ${ }^{5}$, gdy przyszły biskup Noli pędził jeszcze życie bogatego akwitańskiego arystokraty i wielbiciela Muz (Listy 17-20). Celem obecnego artykułu jest przybliżenie tych czterech tekstów. Zapoznanie się z nimi pozwala bowiem lepiej zrozumieć relacje łączące dwóch przyjaciół, którzy darzyli się tak autentycznym,

* Dr hab. Tatiana Krynicka - adiunkt w Katedrze Filologii Klasycznej na Wydziale Filologicznym Uniwersytetu Gdańskiego; e-mail: tatianatko@yahoo.es.

${ }^{1} \mathrm{O}$ losach i spuściźnie literackiej Meropiusza Poncjusza Paulina, biskupa Noli (353-451), por. M. Cytowska - H. Szelest, Literatura rzymska. Okres cesarstwa. Autorzy chrześcijańscy, Warszawa 1994, 183-186; Altaner, s. 536-537. O jego relacjach z Auzoniuszem por. A. Pastorino, Introduzione, w: Opere di Decimo Magno Ausonio, a cura di A. Pastorino, Torino 1971, 11-121, spec. s. 50-55; M. Cytowska, Paulin z Noli uczeń Auzoniusza, „Meander” 49 (1994) 33-42; D. Trout, Paulinus of Nola. Life, Letters and Poems, Berkeley 1999, spec. s. 28-45; T. Krynicka, Decymus Magnus Auzoniusz w świetle własnych utworów, Pelplin 2014, 176-177.

${ }^{2}$ Różni wydawcy ustalają odmienną kolejność listów w zbiorze. W tym artykule analizuję i cytuję utwory Auzoniusza na podstawie wydania: The Works of Ausonius, edited with introduction and commentary by R.P.H. Green, Oxford 1991.

${ }^{3}$ Por. A. Swoboda, Przyjaźń i konflikt Auzoniusza i Paulina z Noli w świetle korespondencji, „Eos” 83 (1995) 307-321; A.M. Wasyl, Rzymski list poetycki. Próba opisania gatunku, Kraków 2002, 69-71, 76-77, 88 i 180-194; J. Pałucki, Świeccy adresaci listów Paulina z Noli, VoxP 22 (2002) t. 42-43, 253-260, spec. s. 256; tenże, Epistolografia Paulina z Noli (355-430). Adresaci oraz okoliczności powstawania listów, w: Fructus Spiritus est Caritas. Księga jubileuszowa ofiarowana ks. prof. F. Draczkowskiemu, red. M. Wysocki, Lublin 2011, 305-314, spec. s. 307; М. Гаспаров, Авсоний и его время, w: Авсоний, Стихотворения, ред. М. Гаспаров, Москва 1993, 251-272, spec. s. 263; Krynicka, Decymus Magnus Auzoniusz, s. 276-279.

${ }^{4}$ Por. S. Pontii Meropii Paulini Nolani Opera, rec. G. de Hartel, CSEL 30, Pragae 1894, 24-42.

${ }^{5}$ Por. L. Mondin, Commento, w: Decimo Magno Ausonio, Epistole, introduzione, testo critico e commento a cura di L. Mondin, Venezia 1995, 59-289, spec. s. 139. 
serdecznym, głębokim przywiązaniem, jak żaden inny spośród znanych nam łacińskich poetów ${ }^{6}$.

1. „Collocutio scripta"7: rozmowa erudytów. Roger Green uważa, że List 17 jest prawdopodobnie najwcześniejszym w zachowanej korespondencji Auzoniusza z Paulinem ${ }^{8}$. Michaił Gasparow przyjmuje, że mógł on powstać w $388 \mathrm{roku}^{9}$. Ostatecznie powinniśmy stwierdzić, że nie jesteśmy w stanie ustalić rocznego datowania utworu ${ }^{10}$, chociaż znamy miesiąc, a nawet dzień jego skomponowania: poeta podaje, że zaczął pisać go w godzinach wieczornych 20. dnia przed styczniowymi Kalendami (tj. 13 XII), a ukończył następnego poranka (14 XII) ${ }^{11}$. Pisał naprędce, gdyż na odpowiedź oczekiwał posłaniec, który poprzedniego wieczoru dostarczył mu przesyłkę Paulina, zawierającą poemat ucznia ${ }^{12}$, będący, być może, prezentem z okazji zbliżających się Saturnaliów (17-21 XII) ${ }^{13}$, a także - jak możemy się domyślać - towarzyszący mu list z prośbą o łaskawe przyjęcie utworu i wyrażenie opinii o nim ${ }^{14}$. Pośpiech nie przeszkodził jednak Auzoniuszowi ułożyć otwierający list krótki, lecz niezwykle uczony poemat, ukazujący porę dnia oraz datę otrzymania przesyłki od przyjaciela za pomocą astronomicznego omówienia ${ }^{15}$, rozbudowanego, kunsztownego, być może nieco zawiłego i tak podniosłego, że odbiorca, oszołomiony obfitością wymyślnych mitologicznych ozdobników, reminiscencji literackich, środków artystycznych, a także zastosowanym epickim metrum ${ }^{16}$, mógłby się spodziewać, iż ma do czynienia z początkiem eposu poświęconego jakiemuś niezwykle doniosłemu wydarzeniu. Jednak wierny swoim upodobaniom Auzoniusz, który w jednym z utworów oświadcza, że znajduje

\footnotetext{
${ }^{6}$ Por. Trout, Paulinus of Nola, s. 68; Wasyl, Rzymski list poetycki, s. 49.

${ }^{7}$ Ambrosius, Epistula 47, 4, PL 16, 1149-1150.

${ }^{8}$ Por. Green, Commentary, w: The Works of Ausonius, s. 233-663, spec. s. 637.

${ }^{9}$ Por. Гаспаров, Примечания, w: Авсоний, Стихотворения, s. 278-348, spec. s. 334.

${ }^{10}$ Por. Mondin, Commento, s. 113.

${ }^{11}$ Por. Ausonius, Epistula 17, 12-13 i 43, ed. Green, s. 215-216.

${ }^{12}$ Por. tamże 17, 44, ed. Green, s. 216.

${ }^{13}$ Por. tamże 17, 9-10, ed. Green, s. 215: „et nonas decimas ab se nox longa kalendas / iugiter acciri celebranda ad festa iubebat". Tegoż zdania są L. Mondin (Commento, s. 112) i M. Gasparow (Примечания, s. 334), tymczasem R.P.H. Green (Commentary, s. 638) uważa, że wspomniane święto było całkowicie obce w środowisku poety. Moim zdaniem, nawet jeśli sprawy miały się właśnie tak, Auzoniusz mógł żywić pewne przywiązanie do tego najbardziej ulubionego spośród rzymskich świąt, por. Catullus, Carmina XIV 15, ed. A. Baehrens: Catulli Veronensis Liber, Lipsiae 1876, 17: „Saturnalibus, optimo dierum”), a w ostateczności odwoływać się do klasycznej rzymskiej tradycji i popisywać się jej znajomością, por. Krynicka, Decymus Magnus Auzoniusz, s. 273-274. O obchodach Saturnaliów i związanych z nimi zwyczajach por. L. Winniczuk, Ludzie, zwyczaje i obyczaje starożytnej Grecji i Rzymu, Warszawa 2006, 508-511.

${ }^{14}$ Por. Ausonius, Epistula 19a, 17-20, ed. Green, s. 218.

${ }^{15}$ Por. tenże, Epistula 17, 1-10, ed. Green, s. 215.

${ }^{16}$ Por. C. Witke, ,Numen Litterarum”. The Old and the New in Latin Poetry from Constatntine to Gregory the Great, Leiden 1971, 7-8.
} 
przyjemność w długim, wytwornym, nie wprost omawianiu tego, o czym chce mówić ${ }^{17}$, „niespodziewanie” przemawia proza, zwięźle i rzeczowo wyznając Paulinowi: „Nie wiesz, jak sądzę, co chcę w tylu wersach powiedzieć. Sam nie jestem zbytnio tego pewny i nie do końca rozumiem, ale domyślam się"18, po czym to, czego się domyśla, streszcza oddając 10 heksametrów w dziesięciu słowach, z których dwa podaje posługując się tradycyjnie stosowanymi skrótami: „Był już późny wieczór przed dziewiętnastym dniem przed Kalendami styczniowymi (kal. Ian.)"'19. Auzoniusz, jak widzimy, dworuje z lubianej przez poetów maniery peryfrastycznego określania czasu i, podobnie jak wielu innych literatów, posługuje się w celu jej sparodiowania podwójnym oznaczeniem pór dnia $\mathrm{i}$ roku ${ }^{20}$. Jednak na tym jego gra z czytelnikiem nie kończy się. Przytoczone zdanie jest bowiem formalnie zdaniem głównym, mimo że zawiera myśl poboczną. O tym, jakie wydarzenie nastąpiło w tak podniośle opisanej scenerii, Burdigalczyk informuje Paulina we wprowadzonym przez cum inversum zdaniu podrzędnym, pisząc: ,gdy dostarczono mi twój niezwykle wytworny list, do którego dołączyłeś wyjątkowo rozkoszny poemat"21. Wypowiadając się w ten sposób poeta niejako umniejsza znaczenie otrzymanej przesyłki, aby już za chwilę nie szczędzić pod jej adresem licznych, kwiecistych pochwat.

Dowiadujemy się, że nadesłany utwór to epitoma historycznego dzieła Swetoniusza $O$ królach ${ }^{22}$, z którego trzech ksiąg do dnia dzisiejszego zachowały się zaledwie nieliczne fragmenty ${ }^{23}$. Burdigalczyk przytacza ustęp poematu poświęcony barbarzyńskim władcom, który wzbudził jego szczególny zachwyt $^{24}$. Zdaniem Auzoniusza Paulin opowiedział o królach Europy, Azji i Afryki biegle i kunsztownie (perite et concinne), śpiewnie i wdzięcznie (modulate et dulciter), podając ich imiona tak, by pierwotne, przysługujące im $\mathrm{w}$ języku ojczystym akcenty (ut tamen veris et primigeniis vocibus sua fastigia non perirent) „odnalazły się" w iktusach łacińskiego heksametru (iuxta naturam Romanorum accentuum ${ }^{25}$. Burdigalczyk wyraża niezwykle pochlebną

${ }^{17}$ Por. Ausonius, Epistula 9b, 7-9, ed. Green, s. 202: „possem absolute dicere, / sed dulcius circumloquar / diuque fando perfruar".

${ }^{18}$ Tenże, Epistula 17, 11-12, ed. Green, s. 215: „nescis, puto, quid velim tot versibus dicere. medius fidius neque ipse bene intellego; tamen suspicor”, tłum. własne.

${ }^{19}$ Tamże 17, 12-13, ed. Green, s. 215, thum. własne.

${ }^{20}$ Por. E.R. Curtius, Literatura europejska i tacińskie średniowiecze, thum. A. Borowski, Kraków 1997, 279-280.

${ }^{21}$ Ausonius, Epistula 17, 13-14, ed. Green, s. 215-216: „cum redditae sunt mihi litterae tuae oppido quam litteratae, his longe iucundissimum poema subdideras", tłum. własne.

${ }^{22}$ Por. tamże 17, 14-15, ed. Green, s. 216.

${ }^{23}$ Por. I. Lewandowski, Historiografia rzymska, Poznań 2007, 330. Zachowane fragmenty wydał A. Reifferscheid: C. Suetonii Tranquilli praeter Caesarum libros reliquiae, Lipsiae 1860, 315-321.

${ }^{24}$ Por. Ausonius, Epistula 17, 18-26, ed. Green, s. 216. Zob. Mondin, Commento, s. 116.

${ }^{25}$ Tamże 17, 27-29, ed. Green, s. 216. O trudnościach, jakie towarzyszyły próbom oddania barbarzyńskich nazw własnych po grecku i po łacinie, piszą również inni starożytni autorzy, por. 
opinię o tekście, jak też o uzdolnieniach literackich ucznia w ogóle. Twierdzi, że w przysłanym mu do oceny wytwornym (tanta elegantia) poemacie Paulinowi udało się osiągnąć to, co było - nawet zdaniem Horacego, do którego słów Burdigalczyk najwyraźniej nawiązuje ${ }^{26}$ - nieosiągalne, jako że sprzeczne z naturą rzeczy, a mianowicie wypowiedzieć się krótko, lecz zarazem jasno ${ }^{27}$. Zadając pytanie retoryczne zachwyca się krasomówstwem ucznia (iam quid de eloquentia dicam?) oraz zapewnia, że może przysiąc, iż nikt wśród należących do młodszej generacji łacińskich poetów (nullum Romanae iuventutis) nie dorównuje Paulinowi pod względem talentu. Wprawdzie dodaje, iż jest to jego prywatna opinia ${ }^{28}$, ale wypowiada ją z całą stanowczością człowieka, który wie, o czym mówi i jest pewien - co podkreśla posługując się synonimami liquido i certe - swoich kompetencji, jakie uprawniaja go do zabrania słowa w danej kwestii. Przyznaje, że ojcowska miłość, którą darzy Paulina, może oślepiać, ale każe uczniowi znosić go, tak jak przystało synowi znosić ojca, nie żądając, by wydał opinię sprzeczną z ojcowskimi uczuciami ${ }^{29}$. Z drugiej strony zapewnia o swej obiektywności, wyznając: „A jednak, choćbym czule (pie) kochał, oceniam szczerze i surowo (sincere ac severe)" ${ }^{30}$. Prosi też Paulina o kolejne utwory, twierdząc, że podobne podarunki sprawiają mu przyjemność i zaszczycają ${ }^{31}$.

Plinius Maior, Naturalis Historia V 1, éd. J. Desanges: Pline l'Ancien, Histoire naturelle, livre V, Paris 1980, 20; Plinius Minor, Epistula VIII 4, 3, ed. J.H. Westcott: Selected Letters of Pliny, Boston 1899, 103; Servius, Commentarii in Vergilii Eclogas VI 3, rec. G. Thilo - H. Hagen: Servii grammatici qui feruntur in Vergilii carmina commentarii, t. 3, Lipsiae 1887, 65. Badacze różnie interpretują tę wypowiedź poety. R.P.H. Green (Commentary, s. 639) twierdzi, że o ile nie jest ona jedynie kolejnym pozbawionym sensu pochlebstwem (adulatory nonsense) pod adresem Paulina, chodzi w niej nie tyle o akcenty, ile o iloczas. M. Gasparow (Примечания, s. 334) uważa, iż według Auzoniusza Paulin zdołał wymienić barbarzyńskich władców, zachowując - tak często jak tylko było to możliwe - oryginalne brzmienie ich imion, a także osiągając zgodność między ich akcentowaniem przyjętym w łacinie oraz tym wynikającym z metrum. L. Mondin (Commento, s. 118) słusznie, moim zdaniem, zaznacza, iż jest bardzo wątpliwe, by Auzoniusz znał sposób wymawiania wspomnianych imion w ojczystych językach noszących je władców. Podobnie jak ja tłumaczy słowa Burdigalczyka B. Combeaud (D.M. Ausonii Burdigalensis, Opuscula omnia. Ausone de Bordeaux, Oeuvres complètes, texte établi, traduit et commenté par B. Combeaud, t. 1, Bordeaux 2010, 467): „Tu as adapté à la metrique latine les vocables authentiques et originaux avec tellement de précision qu'ils n'en perdent pourtant point leurs accents propres".

${ }^{26}$ Por. Horatius, Ars poetica 25, oprac. O. Jurewicz, w: Kwintus Horacjusz Flakkus, Dzieła wszystkie (wydanie polsko-tacińskie), t. 2, Warszawa 2000, 420: „brevis esse laboro, obscurus fio”.

${ }^{27}$ Por. Ausonius, Epistula 17, 16-17, ed. Green, s. 116: „,solus [...] assecutus, quod contra rerum naturam est, brevitas ut obscura non esset".

${ }^{28}$ Por. tamże 17, 16, ed. Green, s. 116: „ut mihi videare”; tamże 17, 31, ed. Green, s. 116: „ita mihi videris".

${ }^{29} \mathrm{~W}$ innym liście Auzoniusz przysięga na zdrowie syna Hesperiusza i Paulina, por. Epistula 19a, 22-23, ed. Green, s. 218: ,ita te et Hesperium salvos habeam”.

${ }^{30}$ Por. tenże, Epistula 17, 32-33, ed. Green, s. 216, thum. własne.

${ }^{31}$ Por. tamże 29-34, ed. Green, s. 216. 
Miłość i podziw, które Auzoniusz żywił wobec swego dawnego wychowanka, z pewnością nie były udawane ani bezpodstawne. Paulin z Noli rzeczywiście należał do najwybitniejszych łacińskich poetów swoich czasów. Jednak czytając ich korespondencję, powinniśmy zdawać sobie sprawę, że jest ona przesiąknięta epistolarną kurtuazją, która cechowała całą późnoantyczną epistolografię ${ }^{32}$. Również komplementowanie utworów literackich skomponowanych przez osoby zaprzyjaźnione było zgodne z praktyką przyjętą wśród ludzi wykształconych i dobrze wychowanych. Przykładowo, Palladiusz we wstępie do poematu $O$ szczepieniu drzew owocowych mówi niejakiemu Pazyfilowi, któremu dedykuje utwór, wprost:

„aprobujesz, cenisz i lubisz te małe książeczki [...] napisane tą oto ręką [...], które $[\ldots]$ tchną tylko wiejską prostotą i, jak przystało na przyjaciela, mało warte słowa pochlebnie oceniasz" ${ }^{\prime 3}$.

Jak widzimy, Auzoniusz nader wylewnie i serdecznie chwali twórczość poetycką Paulina; w niezachowanym liście tego ostatniego również nie brakowało owego ,słodkiego jak miód przymilania się (mellea adulatio) ${ }^{\prime 34}$ wobec adresata. Jego wyraz Burdigalczyk dostrzega we wzmiance o Ikarze i Dedalu, w której widzi aluzję Paulina do siebie samego i do niego. Wypowiedź ucznia o zuchwałym Ikarze, który swym imieniem obdarzył morze ${ }^{35}$ oraz o Dedalu, który dzięki cechującemu go umiarkowaniu dotarł do Kume, mogła urzec intertekstualnego Auzoniusza m.in. tym, że brzmią w niej echa lektury utworów trzech wielkich poetów epoki augustowskiej ${ }^{36}$, cytatem, który Burdigalczyk z lubością przytacza, uczestnicząc w uczonej grze autorów i czytelników, którzy nawiązują symetryczny dialog z wcześniejszymi literatami, umieszczając ich słowa w nowym kontekście, zaopatrując je w odmienne sensy i przekazując dalej, kolejnym kompetentnym odbiorcom, zachęcanym do wzięcia udziału w tej fascynującej, ambitnej zabawie ${ }^{37}$.

${ }^{32}$ Por. Wasyl, Rzymski list poetycki, s. 49; A. Garzya, L'epistolografia letteraria tardoantica, w: tenże, Il mandarino e il quotidiano. Saggi nella letteratura tardoantica e bizantina, Napoli 1983 (zbiór artykułów tegoż autora), 347-365, spec. s. 355.

${ }^{33}$ Por. Palladius, Opus agriculturae 15, 3-8, rec. J. Schmittius: Palladii Rutilii Tauri Aemiliani viri inlustris Opus agriculturae, Lipsiae 1898, 202, thum. I. Mikołajczyk: Rutyliusz Taurus Emilianus Palladiusz, Traktat o rolnictwie, Toruń 1999, 219.

${ }^{34}$ Ausonius, Epistula 17, 35, ed. Green, s. 216, thum. własne.

35 Opływające wyspe Samos Morze Ikaryjskie, por. P. Grimal, Stownik mitologii greckiej i rzymskiej, tłum. M. Bronarska i inni, Wrocław 2008, 159.

${ }^{36}$ Por. Ausonius, Epistula 17, 37-38, ed. Green, s. 216: ,audax Icario qui fecit nomina Ponto / et qui Chalcidicas moderate enavit ad arces"; Vergilius, Aeneis VI 16-17, ed. R. Pichon, w: Virgile, Oeuvres complètes, Paris 1916, 419: ,iter gelidas enavit ad Arctos, / Chalcidicaque levis tandem super astitit arce"; Ovidius, Tristia I 1, 90, ed. A. Riese: P. Ovidii Nasonis, Carmina, Lipsiae 1874, 119: „Icarus, Icariis nomina fecit aquis”; Horatius, Carmina IV 2, 3-4, oprac. O. Jurewicz, w: Kwintus Horacjusz Flakkus, Dzieła wszystkie, t. 1, Warszawa 2000, 311: „vitreo daturus / nomina ponto”.

${ }^{37}$ R.M. Posani (Reminiscenze di poeti latini nella „Mosella” di Ausonio, „Studi Italiani di Filologia Classica” 34:1962, 31-69, spec. s. 64) twierdzi, że Auzoniusz był z powołania i potrzeby 
Wypowiedź ucznia Auzoniusz interpretuje następująco:

„Czyż nie nazywasz bezmyślnością swego buzującego życiem, bujającego w przestworzach zapału (vegetam et sublimem alacritatem), a mnie czyż nie ukazujesz jako męża doświadczonego, wyróżniającego się zbawienną rozwagą i godnego naśladowania przez syna? Jednak rzeczy mają się zgoła inaczej: otóż ty wzbijasz się na wysokości, lecz nie grozi ci upadek; moja starość zadowala się tym, że mocno stoi na nogach"38.

Możemy jedynie domyślać się, czego dotyczą słowa Paulina: odmiennego potraktowania tematu w omawianym przez Auzoniusza poemacie ucznia oraz w jego własnym zbiorku Żywoty cezarów $w^{39}$, odmienności przyjętych przez obu usus scribendi czy też - szerzej rzecz ujmując - różnic ich charakterów. Nie mamy przecież nawet pewności, czy słowa te w ogóle odnoszą się do nich, czy też Auzoniusz wyjaśnia je w ten sposób jedynie żartem. Analizowany list Burdigalczyka od początku bowiem jawi nam się jako radosna i wyszukana zabawa przyjaciół-literatów, którzy znajdują upodobanie we wspólnej lekturze poezji czyjejś i własnej. W ostatnich słowach listu Burdigalczyk ubolewa, że brak wolnego czasu (otium) nie pozwala mu podjąć się rozkosznego obowiązku (oblectabile negotium) napisania Paulinowi bardziej obszernej odpowiedzi, aby w ten sposób pobudzić go do dalszej wymiany tekstami (te ut eliciam), a sobie sprawić przyjemnośćc ${ }^{40}$.

Starożytni epistolografowie oraz teoretycy gatunku definiowali list jako roz-

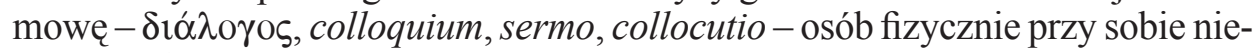
obecnych $^{41}$. List 17 Auzoniusza to zapis rozmowy dwóch bliskich sobie duchowo, choć oddalonych w przestrzeni, przyjaciół - erudytów, których łączy miłość do poetyckiego słowa i pragnienie doskonalenia swego literackiego warsztatu.

2. „Iane veni, novum anne, veni” ${ }^{42}$ : poetów życzenia noworoczne. Jak się wydaje, ma rację Charles Witke, który sądzi, że składający się z 7 dystychów elegijnych, zawierający szereg pochwał adresata List 18, Auzoniusz mógł skomponować z okazji obchodów Nowego Roku ${ }^{43}$. Na rzecz słuszności takiego wniosku przemawia wzmianka o Janusie, któremu Rzymianie, uznając

serca nauczycielem literatury, w związku z czym tworząc własne poezje, stawał się centonistą. O intertekstualności Auzoniusza por. Krynicka, Decymus Magnus Auzoniusz, s. 230-233.

${ }^{38}$ Ausonius, Epistula 17, 39-42, ed. Green, s. 216, tłum. własne.

${ }^{39}$ Por. tenże, Caesares, ed. R.P.H. Green, w: The Works of Ausonius, s. 161-168. Na temat tego zbiorku zob. R.P.H. Green, Ausonius' „,Fasti” and „Caesares” revisited, CQ 49 (1999) 573-578, spec. s. 575-576; Krynicka, Decymus Magnus Auzoniusz, s. 113.

${ }^{40}$ Ausonius, Epistula 17, 44-46, ed. Green, s. 216.

${ }^{41}$ Por. Wasyl, Rzymski list poetycki, s. 38-40.

${ }^{42}$ Ausonius, Precationes variae 2: Precatio consulis designati 1, ed. Green, w: The Works of Ausonius, s. 144.

${ }^{43}$ Por. Witke, ,, Numen Litterarum”, s. 11. 
go za obracającego osią świata ${ }^{44}$ boga wszelkiego początku, poświęcili pierwszy miesiąc roku w systemie kalendarzowym Juliusza Cezara ${ }^{45}$ - oraz skierowane do Paulina życzenie długich lat życia ${ }^{46}$.

Układ listu jest w zasadzie tradycyjny. Rozpoczyna go formuła powitalna, wprawdzie znacznie zmodyfikowana, bo zredukowana do imion piszącego $\mathrm{i}$ adresata, $\mathrm{i}$ to podanych $\mathrm{w}$ odwrotnym niż przyjęty porządku (tj. aliquis alicui salutem dat): najpierw Auzoniusz wymienia odbiorcę, potem nadawcę, z pominięciem słów salutem dicere ${ }^{47}$. Następnie poeta uzasadnia ową odwróconą kolejność, przy czym poszczególne uzasadnienia składają się na pochwalną treść właściwego listu ${ }^{48}$, co sprawia, że formułka salutacyjna - jak trafnie zauważa Anna Maria Wasyl - staje się osią treściową poematu ${ }^{49}$ oraz pozwala niektórym uczonym stwierdzić, że jest on w całości zbudowany na kanwie epistolarnego pozdrowienia $^{50}$. Wreszcie brzmi zwyczajowe pożegnalne ,żyj i bądź zdrów”, połączone, jak już zostało powiedziane, z noworocznymi życzeniami ${ }^{51}$.

„Paulin(o) Ausonius” - tę zaskakującą kolejność korespondentów, których wymienienie składa się na niezwykle krótkie (hemistych pierwszego wersu!) powitanie, Burdigalczyk uzasadnia przede wszystkim wymogami metrum ${ }^{52}$. Zależy mu na uniknięciu rozcinającej daktyl cezury po trocheju trzeciej stopy (caesura trochaice cum posteriore segmento) ${ }^{53}$, a ponadto, jak się wydaje, również na tym, by nie utracić jednego z trzech powodów, dla których uczniowi, w jego odczuciu, przysługuje pierwszeństwo, a które wymienia w kolejności od najmniej do najbardziej ważnego. Jako drugi podaje fakt, że Paulin wyprzedził go w piastowaniu godności konsula ${ }^{54}$; trzeci i najważniejszy widzi w tym, że

${ }^{44}$ Por. Ovidius, Fasti I 120, ed. R. Ehwald - F.W. Levy: P. Ovidius Naso, Fastorum libri VI fragmenta, Lipsiae 1924, 5: ,et ius vertendi cardinis omne meum est”, thum. E. Wesołowska: Owidiusz, Fasti. Kalendarz poetycki, Wrocław 2008, 12.

${ }^{45}$ Por. L. Stankiewicz, Ilustrowany stownik mitologii greckiej i rzymskiej, Wrocław 2008, 190; Winniczuk, Ludzie, zwyczaje i obyczaje starożytnej Grecji i Rzymu, s. 161.

${ }^{46}$ Por. Ausonius, Epistula 18, 13-14, ed. Green, s. 217.

${ }^{47}$ Por. tamże 1-2, ed. Green, s. 217.

${ }^{48}$ Por. tamże 3-12, ed. Green, s. 217.

${ }^{49}$ Por. Wasyl, Rzymski list poetycki, s. 89.

${ }^{50}$ Por. Witke, ,Numen Litterarum”, s. 11; za nim powtarzają tę opinię L. Mondin (Commento, s. 107-108) oraz A.M. Wasyl (Rzymski list poetycki, s. 47-48).

${ }^{51}$ Por. Ausonius, Epistula 18, 13-14, ed. Green, s. 217. Formuła „vive, vale” była powszechnie rozpowszechniona, toteż - wbrew A.M. Wasyl (Rzymski list poetycki, s. 52) - nie wydaje mi się, by jej użycie w omawianym utworze stanowiło odgłos lektury Listów Horacego (Epistulae I 6, 67, oprac. O. Jurewicz, w: Kwintus Horacjusz Flakkus, Dzieła wszystkie, t. 2, s. 285), które skądinąd były Auzoniuszowi doskonale znane, por. D. Nardo, Ausonio e Orazio, „Paideia” 45 (1990) 321-336.

${ }^{52}$ Por. Ausonius, Epistula 18, 1-2, ed. Green, s. 217: „Paulino Ausonius: metrum sic suasit ut esses / tu prior et nomen praegrederere meum".

${ }^{53}$ Brzmiałoby to: „Ausoni /us Pau /lino”; por. Mondin, Commento, s. 109; W. Strzelecki, Zarys metryki łacińskiej, w: Metryka grecka i łacińska, red. W. Strzelecki-M. Dłuska, Wrocław 1959, 107.

${ }^{54}$ Por. Ausonius, Epistula 18, 3-4, ed. Green, s. 217: „quamquam et fastorum titulo prior et tua Romae / praecessit nostrum sella curulis ebur". Zdaniem R.P.H. Greena (Commentary, s. 640) nie 
uczeń przewyższył go w sztuce poetyckiej. Czytamy, że wieńce przyznawane są poematom komponowanym przez obu, ale ten przysługujący Paulinowi zdobi wstęga, którą upiększano najwyższe nagrody ${ }^{55}$. W kolejnych, niezwykle dopracowanych, ozdobionych homoioteleutonami i aliteracjami wersach ${ }^{56}$, Auzoniusz twierdzi, że jego Kamena powstaje, by okazać szacunek Muzie ucznia, ponieważ jako poeta ustępuje on Paulinowi poecie tak bardzo, jak bardzo przewyższa go pod względem wieku ${ }^{57}$. By udowodnić, że przewaga wieku w rzeczywistości nie daje żadnej przewagi, żartobliwie porównuje siebie i ucznia do ptaków: kruka i łabędzia, a także feniksa (opisanego za pomocą uczonej, ozdobnej peryfrazy Gangeticus ales) oraz olśniewająco pięknego pawia, którego łacińska nazwa pavo brzmi podobnie do imienia adresata, a sto (oczek na ogonie) znaczy - paradoksalnie - więcej niż tysiąc (lat przeżytych przez nauczyciela) ${ }^{58}$.

Auzoniusz jawi nam się jako osoba szlachetna i wolna od zawiści. Jest dumny z powodu talentu i osiagnięć wychowanka, m.in. tych literackich. Również w innych swoich utworach wyznaje, że był nie tylko pierwszym nauczycielem Paulina, człowiekiem, który sprzyjał jego karierze politycznej, lecz także rodzicem, przyjacielem, co więcej - wychowawcą jego charakteru ${ }^{59}$ oraz żywicielem $\mathrm{i}$ opiekunem jego talentu (bogate znaczeniowo altor ingenii) ${ }^{60}$, który

ulega wątpliwości, iż Auzoniusz czyni aluzję do piastowanej przez wychowanka godności konsula (consul suffectus). Podobnie uważają C. Witke (,Numen Litterarum”, s. 5) oraz L. Mondin (por. Commento, s. 108-110), którzy datują konsulat Paulina na 378 r. W takiej sytuacji Paulin rzeczywiście wyprzedziłby Auzoniusza, który został pierwszym konsulem w 379 r. (The Prosopography of the Later Roman Empire, t. 1: A.D. 260-395, ed. A.H.M. Jones - J.R. Martindale, Cambridge 1971, 140-141 i 682), aczkolwiek consules suffecti - wbrew Auzoniuszowi, którego pochwały pod adresem przyjaciela po raz kolejny okazują się być nieco na wyrost - nie byli wymieniani w konsularnych $f a-$ sti, por. M.T.W. Arnheim, The Senatorial Aristocracy in the Later Roman Empire, Oxford 1972, 184.

${ }^{55}$ Por. Ausonius, Epistula 18, 5-6, ed. Green, s. 217: „et, quae iam dudum tibi palma poetica pollet, / lemnisco ornata est, quo mea palma caret”. Gramatyk Festus (Sexti Pompei Festi, De verborum significatione quae supersunt cum Pauli Epitome, emendata et annotata a C.O. Muellero, Lipsiae 1839, X (L), s. 115) podaje, że lemnisci to niewielkie kolorowe wstęgi (fasciolae coloriae), zwisające z wieńców (dependentes ex coronis). Pliniusz (Naturalis Historia XXI 6, éd. J. André: Pline l'Ancien, Histoire naturelle, livre XXI, Paris 1969, 28) informuje, że zwyczaj ozdabiania nimi wieńców pochodził od Etrusków.

${ }^{56}$ Inaczej C. Witke (,Numen Litterarum”, s. 11), który uznaje analizowany list za niezbyt dopracowany.

${ }^{57}$ Por. Ausonius, Epistula 18, 11-12, ed. Green, s. 217: „cedimus ingenio, quantum praecedimus aevo; / assurgit Musae nostra Camena tuae". Liczne homoioteleutony znajdujemy również w innych miejscach: w. 7: „longaevae [...] senectae”; w. 9-10: ,annos [...] ales, / oculos [...] tuos”; w. 13: „,venturos [...] Ianos”; a aliteracje: w. 1: „,sic suasit”; w. 5: „palma poetica pollet””; w. 9-10: „vivit [...] vincit”; w. 13: „vive vale”, ed. Green, s. 217.

${ }^{58}$ Por. tamże 9-10, ed. Green, s. 217: ,nec quia mille annos vivit Gangeticus ales / vincit centum oculos, regie pavo, tuos". O tym, gdzie starożytni lokalizowali miejsce stałego pobytu Feniksa por. J. Sawicka, Feniks. Chrześcijańska interpretacja mitu u Laktancjusza, Warszawa 2000, 52-60.

${ }^{59}$ Tak interpretuje tę wypowiedź D. Trout (Paulinus of Nola, s. 29).

${ }^{60}$ Por. Ausonius, Epistula 19b, 24-27, ed. Green, s. 219: ,amicus et vicinus et auctor tuus, / honoris auctor, altor ingenii tui, / dic et «magister», dic «parens»". 
uczynił go czcicielem i przyjacielem Muz ${ }^{61}$. Paulin bez sprzeciwu akceptował te słowa Burdigalczyka, przyznając, że właśnie jemu, „patronowi, mistrzowi, ojcu", zawdzięcza wszystko, co w życiu osiagnął ${ }^{62}$.

Analizowany list jest, jak widzimy, zbudowany na zasadzie porównania nadawcy i odbiorcy. Liczne zaimki 1 i 2 osoby, którymi posługuje się Burdigalczyk $^{63}$, sprawiaja, że odnosimy wrażenie, iż nie tylko ich zestawia, lecz wręcz sobie nawzajem przeciwstawia. Jednak w rzeczywistości łączy go z uczniem niezwykła zażyłość. W pierwszych słowach utworu uwypukla ją poprzez spojenie imienia Paulina ze swoim za pomocą elizji ${ }^{64}$. W ostatnich wersach życzy wychowankowi, aby przeżył tyle lat, ile spędzili na świecie ich ojcowie $^{65}$. Juliusz Auzoniusz, ukochany ojciec Burdigalczyka, przeżył długie, owocne życie. Dożył 90 lat; do końca swoich dni cieszył się dobrym zdrowiem, służył radą i pomocą bliskim, słynął z mądrości i zacnych obyczajów ${ }^{66}$. Wiek rodzica Paulina w chwili, gdy opuszczał świat, nie jest nam znany. Na podstawie analizowanej wypowiedzi możemy jedynie domyślać się, że był równie sędziwy. Jak się wydaje, najbardziej istotnym przesłaniem tych słów jest aluzja do łączącej ich rodziny przyjaźni. Wypowiadając się w ten sposób, Auzoniusz przypomina Paulinowi, że są od dawna - chciałoby się powiedzieć „w którymś pokoleniu” - przyjaciółmi, że odziedziczyli tę przyjaźń po swoich przodkach oraz powinni ją pielęgnować w nadchodzącym roku i przez wiele, wiele szczęśliwych lat, aż do kresu dni ${ }^{67}$.

\section{3. "Accipe fastosum, munera cara, garum" ${ }^{68}$ : prezenty ofiarowane,} przyjmowane, celebrowane. Starożytni chętnie obdarowywali się prezenta$\mathrm{mi}^{69}$. W otoczeniu Burdigalczyka poematy towarzyszyły podarunkom, zawie-

${ }^{61}$ Por. tenże, Epistula 22, 33-35, ed. Green, s. 225: „ego sum tuus altor et ille / praeceptor primus, primus largitor honorum, / primus in Aeonidum qui te collegia duxi”.

${ }^{62}$ Por. Paulinus Nolanus, Carmina 10, 93-96, CSEL 30, 28: „tibi disciplinas dignitatem litteras, / linguae togae famae decus / provectus altus institutus debeo, / patrone praeceptor pater".

${ }^{63}$ Por. Ausonius, Epistula 18, 2: „tu [...] meum”; w. 3: „tua”; w. 4: „nostrum”; w. 5: „tibi”, w. 6 : „mea”; w. 10: „tuos”; w. 12: „nostra [...] tuae”; w. 14: „tuus [...] noster”, ed. Green, s. 217.

${ }^{64}$ Por. tamże 1, ed. Green, s. 217.

${ }^{65}$ Por. tamże 13-14, ed. Green, s. 217.

${ }^{66}$ Por. tenże, Epicedion 61-62, ed. R.P.H. Green, w: The Works of Ausonius, s. 18; tenże, Parentalia 1, 3-4, ed. R.P.H. Green, w: The Works of Ausonius, s. 26-27; Krynicka, Decymus Magnus Auzoniusz, s. 58-70; taż, „Maturam frugem flore manente ferens”. Pochwata starości w poezjach Auzoniusza, VoxP 31 (2011) t. 56, 169-183, spec. s. 171 i 174.

${ }^{67}$ Podobne przekonanie Burdigalczyk zawrze w ostatnim liście do umiłowanego ucznia, por. Epistula 24, 8-11, ed. Green, s. 227: „tam placidum, tam mite iugum, quod utrique parentes / ad senium nostri traxere ab origine vitae / impositumque piis heredibus usque manere / optarunt dum longa dies dissolveret aevum".

${ }^{68}$ Por. Martialis, Epigrammata XIII 102, 2, ed. F.G. Schneidewin: M. Val. Martialis, Epigrammaton libri, Lipsiae 1866, 318.

${ }^{69} \mathrm{O}$ starożytnym zwyczaju obdarowywania gości i przyjaciół, por. L. Winniczuk, Pliniusz Młodszy w świetle swoich mów i listów, Warszawa 1987, 362-363. 
rały wytworne podziękowanie za te otrzymane, zapowiedź wzajemnego obdarowania oraz obietnicę... napisania innych poematów. Uczone i dopracowane do granic zmanierowania utwory Auzoniusz skomponował, aby podziękować niejakiemu Teonowi, drobnemu właścicielowi ziemskiemu i poecie-amatorowi, za otrzymane od niego ostrygi ${ }^{70}$ oraz wyśmienite, sławne także dziś medulickie (z Medullium, obecnie Médoc) jabłka, które - jak ani trochę nie krępując się wyznaje obdarowany - były o niebo lepsze niż dołączone do nich wiersze darczyńcy ${ }^{71}$. Lektura listów do Teona przekonuje nas, że Burdigalczyk był prawdziwym smakoszem, lubił smacznie zjeść i umiał celebrować otrzymywane od przyjaciół w prezencie smakołyki ${ }^{72}$. Aby zadowolić wyrobione podniebienie mistrza, Paulin przysyła mu kilka rodzajów wyśmienitej hiszpańskiej oliwy oraz wyprodukowany w Barcino (obecnie Barcelona) delikatesowy sos garum sociorum ${ }^{73}$ - wytwarzany z makreli najsłynniejszy gatunek garum, mający postać złocistego, przezroczystego płynu o charakterystycznym, mocnym zapachu i wyraźnym, słonym smaku ${ }^{74}$. Auzoniuszowy List 19 to przede wszystkim podziękowanie za wspaniały prezent. Burdigalczyk wyznaje, że nie jest w stanie zmusić siebie do określania kosztownego sosu będącą w powszechnym użyciu (quo in usu vulgi est) nazwą muria, choć z drugiej strony zdaje sobie sprawę, że najbardziej uczeni spośród dawnych autorów, którzy czuli odrazę do greki (Graeca vocabula fastidientes), nie znali słowa „garum"75. W żartobliwym wierszyku zapewnia Paulina, że niezależnie od tego, jak powinno się nazywać luksusowy płyn, zazwyczaj ustawiany na stole, by biesiadnicy jedynie pokrapiali nim czy zanurzali w nim potrawy ${ }^{76}$, natychmiast obficie poleje nim ugotowane na miękko jajka ${ }^{77}$, które nazywa dodającym tekstowi dostojeństwa archaicznym wyrazem apalaria $^{78}$.

${ }^{70}$ Por. Ausonius, Epistula 13b, ed. Green, s. 212-213.

${ }^{71}$ Por. tenże, Epistula 16, 1, ed. Green, s. 215: ,aurea mala, Theon, sed plumbea carmina mittis"; H. Sivan, Ausonius of Bordeaux. Genesis of a Gallic aristocracy, London 1993, 72-73.

${ }^{72}$ Więcej o upodobaniach gastronomicznych Burdigalczyka, por. Krynicka, Decymus Magnus Auzoniusz, s. 186-188.

${ }^{73}$ Por. Ausonius, Epistula 19a, 1-7, ed. Green, s. 217. Zob. R. Étienne, Ausone et l'Espagne, w: Mélanges d'archéologie, d'épigrahie et d'histoire oferts a Jérôme Carcopino, éd. J. Heurgon G. Picard, Paris 1966, 319-332, spec. s. 323-325.

${ }^{74}$ Por. J. André, L'alimentation et la cuisine à Rome, Paris 1961, 199; M. Kokoszko, Ryby i ich znaczenie w życiu codziennym ludzi późnego antyku i wczesnego Bizancjum (III-VII w.), Łódź 2005, 373-374.

${ }^{75}$ Por. Ausonius, Epistula 19a, 4-7, ed. Green, s. 217.

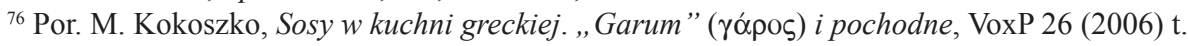
49, 289-298, spec. s. 292.

${ }^{77}$ Przepis na sos do jaj ugotowanych na miękko (in ovis hapalis) przyrządzany na bazie garum podaje Apicjusz (De re coquinaria VII 17, 3, oprac., thum. i komentarz I. Mikołajczyk - S. Wyszomirski: Apicjusz, O sztuce kulinarnej ksiag dziesięć, tekst łacińsko-polski, Toruń 1997, 190).

${ }^{78}$ Por. Ausonius, Epistula 19a, 8-9, ed. Green, s. 217: ,iam patinas implebo meas, ut parcior ille / maiorum mensis apalaria sucus inundet"; E. Di Lorenzo, Ausonio. Saggio su alcune componenti stilistiche, Napoli 1980, 38. 
Mimo wysokiej ceny podarku ${ }^{79}$, jego wartość w odczuciu Burdigalczyka zdecydowanie ustępowała wartości dołączonego do niego „bileciku”. W otwierającej list partii prozowej Auzoniusz nie kryjąc wzruszenia i nie zważając na to, że popada w przesadę, wyznaje (stosując trzykrotnie powtórzoną eksklamację), że dzięki cechującej go słodyczy przyjaciel przewyższa miód, pod względem wdzięku nie dorównują mu Gracje, zasługuje też na uścisk wszystkich ojców świata ${ }^{80}$. O ile jednak ktoś wyjątkowy mógłby dorównać wspaniałomyślności Paulina, który odrywa od ust łakomy kąsek, by podzielić się nim z mistrzem, nikt nigdy nie będzie w stanie naśladować uczoności jego listów (de epistularum tuarum eruditione), jak również powabu i pomysłowości w doborze tematyki oraz mistrzowskiej kompozycji jego poezji (de poematis iucunditate, de inventione et concinnatione) ${ }^{81}$. Auzoniusz obiecuje uczniowi, że jedynie ulegając jego prośbom gorliwie wygładzi (exquisitim universa limabo) przysłane przez niego doskonałe poezje ${ }^{82}$. Dołącza też krótki - jak twierdzi - utwór jambiczny, będący szkicem przyszłego poematu w heksametrach, o który usilnie prosi nauczyciela Paulin ${ }^{83}$. Burdigalczyk przysięga na życie najdroższych mu osób, iż stworzył go naprędce, w ciagu jednej nocy ${ }^{84}$, po to tylko, aby - jak żartobliwie się tłumaczy - posłaniec adresata nie odszedł bez nagrody za fatyge (sine corollario poetico) ${ }^{85}$.

Ów wierszowany „,napiwek” to w rzeczywistości składający się z 46 wersów kunsztowny poemat, który zgodnie z wymogami estetyki literackiej okresu cesarstwa łączy finezję formy z erudycyjnością treści ${ }^{86}$. Po raz kolejny ${ }^{87}$ nawiązując do zabiegu stosowanego już wcześniej przez autorów tej miary, co Katullus, Horacy, Owidiusz czy Marcjalis ${ }^{88}$, Burdigalczyk zwraca się do

${ }^{79}$ Por. M. Żmudziński, Kilka słów o zbytku - spożyciu kosztownych przysmaków w rzymskich prowincjach $w$ dobie Cesarstwa, w: Zbytek i ubóstwo w starożytności i średniowieczu, red. L. Kostuch - K. Ryszewska, Kielce 2010, 245-251, spec. s. 249-250.

${ }^{80}$ Por. Ausonius, Epistula 19a, 11-13, ed. Green, s. 217-218: „o melle dulcior, o Gratiarum venustate festivior, o ab omnibus patrio stringende complexu!"

${ }^{81}$ Tamże 13-16, ed. Green, s. 217-218: ,sed hoc atque alia huiusmodi documenta liberalis animi aliquis fortasse et aliquando, quamvis rarum; illud de epistularum tuarum eruditione, de poematis iucunditate, de inventione et concinnatione, iuro omnia nulli umquam imitabile futurum, etsi fateatur imitandum".

${ }^{82}$ Por. tamże 17-22, ed. Green, s. 218.

${ }^{83}$ Por. tamże 21, ed. Green, s. 218: ,paucis iambicis praeludendum putavi, dum illud quod a me heroico metro desideras incohatur".

${ }^{84}$ Por. tamże 22-24, ed. Green, s. 218: ,isti tamen [...] spatio lucubratiunculae unius effusi”. Zob. Mondin, Commento, s. 133.

${ }^{85}$ Ausonius, Epistula 19a, 20-21, ed. Green, s. 218.

${ }^{86}$ Por. J. Styka, Sydoniusz Apollinaris i kultura literacka w Galii Vwieku, Kraków 2008, 69-75.

${ }^{87}$ Por. Ausonius, Epistula 19b, 1-6, ed. Green, s. 218.

${ }^{88}$ Por. Catullus, Carmina 42, 1-2, ed. Baehrens, s. 35; Horatius, Epistulae I 20, oprac. Jurewicz, t. 2, s. 360-362; Ovidius, Tristia I 1, 1-3, ed. Riese, s. 117; Martialis, Epigrammata I 96 i VII 26, ed. Schneidewin, s. 33-34 i 156. Więcej na temat stosowanej przez rzymskich poetów alokucji do personifikowanych własnych dzieł pisze A.M. Wasyl (Rzymski list poetycki, s. 22-23 i 45-47). 
własnego utworu ${ }^{89}$ : wyprawia go do Paulina ${ }^{90}$, wkłada mu w usta słowa, które ma wychowankowi przekazać ${ }^{91}$, pozdrawiając go ${ }^{92}$ oraz odpowiadając na jego pytania $^{93}$, wreszcie nakazuje poematowi jak najszybciej powracać do domu ${ }^{94}$. Zauważmy, że postępując w ten sposób Auzoniusz podejmuje swego rodzaju grę z rzeczywistym odbiorca, którym jest Paulin: nie zwraca się doń wprost, ale za pośrednictwem utworu, który doń kieruje; mówi o nim, jak gdyby w jego obecności - do osoby trzeciej; zręcznie unika konieczności odpowiadania na ewentualne pytanie Paulina o ocenę jego wierszy ${ }^{95}$.

Słowo-klucz listu to velocitas - „szybkość”. Szybkie są jamby: bardziej lotne (velocior) od partyjskich i kreteńskich strzał oraz skrzydeł ptaków, bardziej wartkie (torrentior) od rwącej rzeki Pad, spadające gęściej (densior) niż huczący grad, rozbłyskujące częściej (vibratior) niż ogniste błyskawice ${ }^{96}$. Auzoniusz przypomina, iż zgodnie z legendą właśnie jamby jako pierwsze spośród wszystkich miar wierszowych wydobyły się z wód źródła Hippokrene, które wybił ze skały uderzeniem kopyta Pegaz, koń - o czym doskonale wie kompetentny czytelnik - niecierpliwy i lotny. Nie poprzestając na tym, wyposaża swe wiersze w skrzydlate sandały Perseusza oraz Hermesowy podróżny kapelusz o szerokim rondzie i nakazuje skomponowanemu w tak szybkim metrum poematowi, by szybkostopy i uskrzydlony, niczym wysoko wzlatujący na szczę́sliwą wróżbę ptak (praepes et volucripes) pomknął do Paulina, zaniósł mu pozdrowienia i natychmiast, po odzyskaniu sił, wybierał się z powrotem ${ }^{97}$, przywożąc ze sobą jakiś niewielki prezent pochodzący z obficie zaopatrzonej literackiej komory adresata ${ }^{98}$. Chce, by posłaniec powrócił, zanim skończy do niego mówić ${ }^{99}$, naśladując swego twórcę, który trzykrotnie przemknął nad zionącą ogniem Chimerą tak szybko i zręcznie, że buchające tuż obok niego płomienie nie wyrządziły mu krzywdy ${ }^{100}$.

Twórca analizowanego poematu ukazuje się jako pełen dowcipu i fantazji literat, który potrafi wyrazić najbardziej banalne treści w sposób pomysłowy,

\footnotetext{
${ }^{89}$ Por. Ausonius, Epistula 19b, 1, ed. Green, w. 218: „Iambe”.

${ }^{90}$ Por. tamże 1-13, ed. Green, s. 218.

${ }^{91}$ Por. tamże 14-43, ed. Green, s. 218-219.

${ }^{92}$ Por. tamże 14-28, ed. Green, s. 218.

${ }^{93}$ Por. tamże 29-43, ed. Green, s. 219.

${ }^{94}$ Por. tamże 44-46, ed. Green, s. 219.

${ }^{95}$ Por. tamże 29-31, ed. Green, s. 219.

${ }^{96}$ Por. tamże 1-5, ed. Green, s. 218.

${ }^{97}$ Por. tamże 16-18, ed. Green, s. 218.

${ }^{98}$ Por. tamże 44-46, ed. Green, s. 219: „haec fare cursim nec moratus pervola, / aliquid reportans interim munusculi / de largitate musici promptarii”; por. Epistula Theodosii Augusti [Ausonio] w. 7-8, ed. R.P.H. Green, w: The Works of Ausonius, s. 707: ,quae [scil. opera tua] tu de promptuario scriniorum tuorum, qui me amas, libens imperties".

${ }^{99}$ Por. Epistula 19b, 19, ed. Green, s. 219: „nihil moreris iamque dum loquor redi”.

${ }^{100}$ Por. tamże 21-22, ed. Green, s. 219.
} 
kunsztowny, a nawet zmanierowany ${ }^{101}$, co więcej - jako kochający życie człowiek, który rozkoszuje się smakiem wyszukanych potraw i wyszukaną wirtuozerią wierszy, a nade wszystko miłością przyjaciół jako najcenniejszym spośród darów, jakie od nich otrzymuje.

\section{4. ,Amicus certus in re incerta cernitur" ${ }^{102}$ : na ratunek przyjacielowi.} Czytając listy Burdigalczyka, możemy dojść do wniosku, że w jego środowisku pisano do siebie głównie dla samej przyjemności pisania, niezwykle rzadko opowiadając o swoich potrzebach, prosząc o przysługi, wyrażając wdzięczność za otrzymane wsparcie, jak to mają w zwyczaju czynić zwykli śmiertelnicy. Jedyną w całym dorobku epistolarnym Auzoniusza aluzję do realnych problemów, którym musiał stawiać czoła ${ }^{103}$, znajdujemy w skierowanym do Paulina Liście 20. Utwór jest typowym listem polecającym, epistola commendaticia. W rozbudowanym wstępie (insinuatio), mającym usposobić adresata do życzliwego przyjęcia prośby oraz zapoznać go z polecaną osobą, Auzoniusz wylewnie dziękuje Paulinowi za niezmienną życzliwość i liczne przysługi ${ }^{104}$, po czym opisuje kolejną kłopotliwą sytuację, która zmusza go do proszenia przyjaciela o pomoc i, rzecz jasna, inspiruje do napisania wiersza. Poeta wyłuszcza bowiem Paulinowi sprawę dwukrotnie, najpierw prozą, zgodnie z zaleceniami retorów zwięźle, jasno i dokładnie ${ }^{105}$, a następnie - za pomocą jambów, barwnie i szczegółowo. Dowiadujemy się, iż niegdysiejszy zarządca majątku Auzoniusza Filon nabył od rolników żywność, którą następnie zmagazynował w Hebromagum (obecnie Langon) ${ }^{106}$. Niebawem zawiadujący magazynami słudzy Paulina zagrozili, że przed czasem usuną towar z zajmowanych pomieszczeń. W tej sytuacji Auzoniusz prosi wychowanka, aby zezwolił Filonowi na przechowywanie żywności dotąd, aż będzie on mógł załadować ją na statek i przetransportować do miasta, w ten sposób ratując przed niedostatkiem zarówno własną rodzinę, jak też poetę i jego domowników zgromadzonych w posiadłości Lukanikum ${ }^{107}$.

${ }^{101}$ Por. Di Lorenzo, Ausonio, s. 17-18; Witke, ,, Numen Litterarum”, s. 5 i 14; Krynicka, Decymus Magnus Auzoniusz, s. 202-204.

102 Por. Ennius, Varia fragmenta 428, rec. J. Vahlen: Ennianae reliquiae, Lipsiae 1854, 146; Ennius apud Ciceronem: Laelius de amicitia liber 17, 64, rec. C.F.W. Müller, w: M. Tulli Ciceronis, Opera, Lipsiae 1909, 162-196, spec. s. 184).

${ }^{103}$ Zwraca na to uwagę również W.H.C. Frend (Paulinus of Nola and the Last Century of the Western Empire, JRS 59 (1969) 1-11, spec. s. 3).

${ }^{104}$ Por. Ausonius, Epistula 20a, 1-3, ed. Green, s. 219-220: „Multas et frequentes mihi gratiae tuas causas et occasio subinde nata concinnat et naturae tuae facilitas benigna conciliat, Pauline fili. Nam quia nihil poscente me annuis, magis acuis procaciam quam retundis". Zob. R. Andrzejewski, Struktura antycznego listu polecajacego w świetle zasad retoryki, RH 21 (1973) z. 3, 17-24, spec. s. 17-19; Witke, ,,Numen Litterarum”, s. 17.

${ }^{105}$ Por. Andrzejewski, Struktura antycznego listu polecajacego, s. 21.

${ }^{106}$ Por. R. Étienne, Bordeaux antique, Bordeaux 1962, 357-359; Green, Commentary, s. 642643. C. Witke (,Numen Litterarum”, s. 12) utożsamia Hebromagum z leżącymi w pobliżu Bordeaux Bran lub Villerazons.

${ }^{107}$ Por. Ausonius, Epistula 20a, 4-11, ed. Green, s. 220. 
Zauważa, że jeśli Filon straci swój towar, jego rodzina nie doczeka się zaopatrzenia w zboże, o którym pisze Cyceron - domyślamy się, że Burdigalczykowi chodzi o trzecią księgę mowy oskarżycielskiej przeciwko Werresowi ${ }^{108}$ - ale znajdzie się w sytuacji omdlewającego z głodu pasożyta Kurkuliona, tytułowego bohatera jednej z komedii Plauta ${ }^{109}$.

Druga część analizowanego listu to poemat, w którym Auzoniusz, popisując się umiejętnością opowiadania tychże treści prozą i wierszem, po raz drugi opowiada Paulinowi o trudnej sytuacji, w której wraz z Filonem znalazł się on sam i jego bliscy. Twierdzi, że jego jamby mają pełnić rolę swego rodzaju poetyckiej pieczęci, którą adresat bez trudu rozpozna i będzie bardziej skłonny do spełnienia zawartej w liście, a nie dotyczącej przecież bezpośrednio Auzoniusza, prośby - czy to z miłości do nadawcy, czy to ze strachu przed otrzymaniem kolejnego jego poematu. Porównuje swe wiersze nie do własnoręcznych dopisków, umieszczanych na końcu dyktowanych listów, ani nie do pieczęci nanoszonej za pomocą specjalnego pierścienia (anulus signatorius) ${ }^{110}$, lecz do wypalanego piętna; przy czym rzeczownik character oznacza również styl literackiego utworu, w tym przypadku - jego niepowtarzalny, łatwy do rozpoznania styl ${ }^{111}$.

W odróżnieniu od pierwszej części listu, poemat zawiera rozbudowaną, pełną aluzji literackich, skrzącą się dowcipem opowieść o Filonie ${ }^{112}$. Auzoniusz opisuje wygląd zewnętrzny protegowanego, jego charakter, a także łączące ich od lat relacje. Ekonom poety to siwy, zarośnięty, kudłaty, zapalczywy starzec o czarnym podniebieniu (ukuty przez poetę neologizm atribux ${ }^{113}$ ) i najeżonych włosach, którego charakter jest równie szpetny co wygląd; marny gospodarz, który na stare lata postanowił zająć się handlem. Robienie z nim interesów przynosi nadawcy jedynie straty, ale sam Filon potrafi mimo wszystko się wzbogacić $^{114}$, niczym sprytny oszust-niewolnik z Plautyńskich komedii. Filon kojarzy się Auzoniuszowi z Terencjuszowym Formionem - zuchwałym, przebiegłym

${ }^{108}$ Por. K. Kumaniecki, Cyceron i jego współcześni, Warszawa 1959, 118-120.

${ }^{109}$ Por. Ausonius, Epistula 20a, 10-11, ed. Green, s. 220: „tota illa familia [...] non ad Tulli frumentariam sed ad Curculionem Plauti pertinebit”. Zob. Krynicka, Decymus Magnus Auzoniusz, s. 205-207 i 209; Green, Commentary, s. 645.

${ }^{110}$ Por. L. Małunowiczówna, Wstęp, w: Antologia listu starochrześcijańskiego, t. 1: Listy z dziedziny kierownictwa duchowego, Lublin 1978, 7-63, spec. s. 9.

${ }^{111}$ Por. Ausonius, Epistula 20a, 11-16, ed. Green, s. 220: „hoc quo facilius impetrarem aut quo maiorem vereris molestiam si negares, concinnatam iambis signatamque ad te epistulam misi, ne subornatum diceres tabellarium si a te sine signi fide veniret. signavi autem $[\ldots]$ per poeticum characterem". Zob. Mondin, Commento, s. 141; B. Combeaud, Commentaire, w: D.M. Ausonii Burdigalensis, Opuscula omnia, t. 1, s. 623-808, spec. s. 788.

${ }^{112}$ Por. Ausonius, Epistula 20b, ed. Green, s. 220-222.

${ }^{113}$ Por. Di Lorenzo, Ausonio, s. 80.

${ }^{114}$ Por. Ausonius, Epistula 20b, 33-34, ed. Green, s. 221: ,ac lucra damnis, damna mutans fraudibus / se ditat et me pauperat". 
grabieżcą cudzego mienia i wykrętnym gwałcicielem praw ${ }^{115}$, a także z morskim jeżem o igłach sterczących niczym włosy Horacjuszowej wiedźmy Sagany ${ }^{116}$, okropnym i kłującym niczym... wiersze samego Burdigalczyka! ${ }^{117}$

Jak się wydaje, Auzoniusz celowo przesadza wystawiając byłemu słudze tak niepochlebną, prześmiewczą opinię. Pewny tego, że uda mu się rozbawić Paulina ujętymi w jamby dowcipnymi ploteczkami, w analizowanym poemacie prosi już nie tylko o to, by Filon mógł korzystać z magazynów Paulina aż do czasu, gdy załaduje swój towar na odpowiedni statek, lecz idzie dalej, sugerując, że adresat mógłby wsadzić pechowego kupca na jakikolwiek, nawet własny (!), statek, by dostarczył on Burdigalczykowi długo oczekiwane zboże, a zarazem uwolnił Paulina od swej obecności ${ }^{118}$. Dystansuje się od Filona, oświadcza, że niechętnie wstawia się za nim u przyjaciela ${ }^{119}$. Z drugiej jednak strony, jak przystało autorowi listu polecającego, podkreśla, że los jego samego i jego najbliższych zależy od łaskawości Paulina, którego - o ile pomoże im otrzymać wiezioną przez Filona żywność - będzie czcił bardziej niż Ceres i Triptolemosa ${ }^{120}$. Umie zatem prosić zarazem delikatnie, jak też usilnie, a będąc pewnym, że przyjaciel nie odmówi mu kolejnej przysługi, beztrosko - na pozór - żartuje, zachowuje optymistyczny dystans wobec opisywanych trudności, bawi się aluzjami literackimi oraz dokonuje swoistej sielankowej stylizacji kłopotów ${ }^{121}$, z którymi zmierza się na co dzień w zgoła nie sielankowej, pełnej niepewności rzeczywistości ${ }^{122}$, a które ma nadzieję rozwiązać z pomocą wiernego przyjaciela.

Jak słusznie zauważa Charles Witke, każdy, kto podejmuje się studiowania historii łacińskiej literatury IV w., powinien zapoznać się z historią dramatycznej

${ }^{115}$ Por. M. Brożek, Terencjusz, Wrocław 1960, 207-212; R.P.H. Green, The Correspondence of Ausonius, AC 49 (1980) 191-211, spec. s. 208.

${ }^{116}$ Por. Horatius, Epodon librum 5, 25-28, oprac. O. Jurewicz, w: Kwintus Horacjusz Flakkus, Dzieła wszystkie, t. 1, s. 393: ,at expedita Sagana per totam domum / spargens Avernalis aquas / horret capillis ut marinus asperis / echinus aut currens aper".

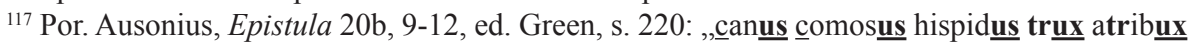
/ Terentianus Phormio, / horrens capillis ut marinus asperis / echinus aut versus mei”".

${ }^{118}$ Por. tamże 39-42, ed. Green, s. 221: ,hunc ergo paucis ne graveris hospitem / ***/ adiutus ut mox navis auxilio tuae / ad usque portus oppidi”.

${ }^{119}$ Por. tamże 5-6, ed. Green, s. 220: „,suis querellis asserit nostras preces, / quas ipse lentus prosequor".

${ }^{120}$ Por. tamże 45-50, ed. Green, s. 221-222. Zob. Andrzejewski, Struktura antycznego listu polecajacego, s. 22-23.

${ }^{121}$ Por. Pastorino, Introduzione, s. 40; Trout, Paulinus of Nola, s. 58.

122 Opinia wbrew F.J. Lomas Salmonte (,, Secessus in villam”: la alternativa pagana al ascetismo cristiano en el círculo de Ausonio, „Antigüedad Cristiana” 8 (1990) 273-286, spec. s. 278), który uważa, że pędzący beztroski żywot poeta konstruuje opisywaną w analizowanym liście sytuację dla rozbawienia odbiorcy. 
przyjaźni Auzoniusza oraz Paulina z Noli ${ }^{123}$. Ich wczesna korespondencja, znana nam, niestety, jedynie na podstawie czterech utworów Burdigalczyka, jest jednak wolna od dramatyzmu, ale pełna dowodów serdecznego przywiązania, głębokiego, wolnego od zawiści podziwu oraz szczerej, nieudawanej sympatii. Treść i ton listów są zróżnicowane. Burdigalczyk dziękuje przyjacielowi za przysłane podarunki; chwali otrzymane od Paulina poematy oraz zapowiada wysłanie mu własnych utworów; snuje refleksje o twórczości literackiej; składa noworoczne życzenia, jak również opowiada o kłopotach dnia codziennego oraz prosi o wyświadczenie przysług. Zasługuje na uwagę formalne dopracowanie i urozmaicenie utworów. Tylko jeden spośród nich (List 18) jest w całości wierszowany. Pozostałe zawierają partie spisane prozą i wierszem, przy czym na List 17 składa się wierszowany wstęp oraz właściwy list spisany proza, który urozmaicają obszerne cytaty z poematu Paulina; w Liście 19 znajdujemy dwa utwory poetyckie skomponowane przez Auzoniusza (żartobliwy epigramat o luksusowym sosie oraz poemat będący rzekomo poetyckim napiwkiem dla posłańca); List 20 to - stosując określenie Luki Mondina - epistola doppia ${ }^{124}$, list podwójny, w którym część poetycka (List 20b) stanowi opracowanie wierszem tematu przedstawionego w części prozowej (List 20a). Uderzające jest bogactwo stosowanych przez Burdigalczyka miar wierszowych, skądinąd charakterystyczne dla całej jego twórczości. W analizowanych listach stosuje on: heksametr (Listy 17, 1-10; 19, 8-9), dystych elegijny (List 18), trymetr jambiczny (List 19b) oraz dystych epodyczny (List 20b).

Mimo że wczesne listy Paulina do mistrza nie zachowały się, przez co słyszymy jedynie połowę prowadzonego przez nich dialogu, lektura analizowanych utworów pozwala stwierdzić, że pochodzenie, status społeczny, a przede wszystkim kultura literacka połączyły dwóch poetów więzami, których zerwanie rzeczywiście kosztowało podeszłego w latach Auzoniusza zbyt wiele i miało prawo zaowocować pełnymi goryczy wierszami, jakie wypełniły ostatnie lata jego ziemskiego życia.

\section{THE EARLY CORRESPONDENCE BETWEEN AUSONIUS AND PAULINUS OF NOLA}

\section{(Summary)}

The article is devoted to the four letters written by Ausonius to Paulinus of Nola before the latter left Aquitania in 389 changing his style of life and provoking the deep crisis of their intimate friendship (Epist. 17-20, ed. R.P.H. Green).

${ }^{123}$ Por. Witke, ,, Numen Litterarum”, s. 3.

${ }^{124}$ L. Mondin (Commento, s. 127 i139) używa tego wyrażenia na określenie wszystkich listów, które zawierają ustępy wierszowane i prozaiczne. Ja nazywam tak tylko List 20, który składa się z partii wierszowanej i prozowej o podobnej treści. 
Ausonius writes to his pupil, admirer and friend about literary theory and practice, thanks for the gifts and favours, asks for help in an hour of need, sends him new year's wishes. The exchange of letters provided to the famous befriended poets an opportunity to participate in the jolly literary games and to share mutual respect, admiration and love.

Key words: Ausonius, Paulinus of Nola, exchange of letters, poetical epistles, letters of reference, friendship in the ancient world.

Slowa kluczowe: Auzoniusz, Paulin z Noli, korespondencja, listy poetyckie, listy polecające, przyjaźń w starożytnym świecie.

\section{BIBLIOGRAFIA}

\section{Źródła}

Ambrosius Mediolanensis, Epistula 47, PL 16, 1149-1151.

ApIcIus, De re coquinaria, oprac., tłum. i komentarz I. Mikołajczyk - S. Wyszomirski: Apicjusz, O sztuce kulinarnej ksiag dziesięć, tekst łacińsko-polski, Toruń 1997.

Ausonius, Caesares, ed. R.P.H. Green, w: The Works of Ausonius, Oxford 1991, 161-168. Ausonius, Epicedion, ed. R.P.H. Green, w: The Works of Ausonius, Oxford 1991, 16-18.

Ausonius, Epistulae, ed. B. Combeaud, w: D.M. Ausonii Burdigalensis, Opuscula omnia. Ausone de Bordeaux, Oeuvres complètes, t. 1, Bordeaux 2010, 422-497.

Ausonius, Epistulae, ed. R.P.H. Green, w: The Works of Ausonius, Oxford 1991, 193-231. Ausonius, Parentalia, ed. R.P.H. Green, w: The Works of Ausonius, Oxford 1991, 25-41.

Ausonius, Precationes variae, ed. R.P.H. Green, w: The Works of Ausonius, Oxford 1991, 143-145.

Catullus, Carmina, ed. A. Baehrens: Catulli Veronensis Liber, Lipsiae 1876.

EnNius [apud Ciceronem]: Laelius de amicitia liber, rec. C.F.W. Müller, w: M. Tulli Ciceronis, Opera, Lipsiae 1909, 162-196.

EnNius, Varia fragmenta, rec. J. Vahlen: Ennianae reliquiae, Lipsiae 1854.

Epistula Theodosii Augusti [Ausonio], ed. R.P.H. Green, w: The Works of Ausonius, Oxford 1991, 707.

Festus Sextus Pompeius, De verborum significatione quae supersunt cum Pauli Epitome, emendata et annotata a C.O. Muellero, Lipsiae 1839.

Horatius Quintus Flaccus, Ars poetica, oprac. O. Jurewicz, w: Kwintus Horacjusz Flakkus, Dzieła wszystkie (wydanie polsko-łacińskie), t. 2, Warszawa 2000, 418-467.

Horatius Quintus Flaccus, Carmina, oprac. O. Jurewicz, w: Kwintus Horacjusz Flakkus, Dzieła wszystkie (wydanie polsko-łacińskie), t. 1, Warszawa 2000, 58-363.

Horatius Quintus Flaccus, Epistulae, oprac. O. Jurewicz, w: Kwintus Horacjusz Flakkus, Dzieła wszystkie (wydanie polsko-łacińskie), t. 2, Warszawa 2000, 248-415.

Martialis, Epigrammata, ed. F.G. Schneidewin: M. Val. Martialis, Epigrammaton libri, Lipsiae 1866.

Ovidius, Carmina, ed. A. Riese: P. Ovidii Nasonis, Carmina, Lipsiae 1874.

Ovidius, Fasti, ed. R. Ehwald - F.W. Levy: Fastorum libri VI fragmenta, Lipsiae 1924, tłum. E. Wesołowska: Owidiusz, Fasti. Kalendarz poetycki, Wrocław 2008.

Palladius, Opus agriculturae, rec. J. Schmittius: Palladii Rutilii Tauri Aemiliani viri inlustris Opus agriculturae, Lipsiae 1898, tłum. I. Mikołajczyk: Rutyliusz Taurus Emilianus Palladiusz, Traktat o rolnictwie, Torun 1999. 
Paulinus Nolanus, Carmina, rec. G. de Hartel: S. Pontii Meropii Paulini Nolani Carmina $X-X I$, CSEL 30, Pragae 1894, 24-42.

Plinius Maior, Naturalis Historia, éd. J. Desanges: Pline l'Ancien, Histoire naturelle, livre V, Paris 1980; Naturalis Historia, éd. J. André: Pline l'Ancien, Histoire naturelle, livre XXI, Paris 1969.

Plinius Minor, Epistulae, ed. J.H. Westcott: Selected Letters of Pliny, Boston 1899.

Servius, Commentarii in Vergilii Eclogas, rec. G. Thilo - H. Hagen: Servii grammatici qui feruntur in Vergilii carmina commentarii, t. 3, Lipsiae 1887.

Suetonius, De regibus, ed. A. Reifferscheid: C. Suetonii Tranquilli praeter Caesarum libros reliquiae, Lipsiae 1860, 315-321.

Vergilius, Aeneis, éd. R. Pichon, w: Virgile, Oeuvres complètes, Paris 1916, 252-671.

\section{Opracowania}

ANDRÉ J., L'alimentation et la cuisine à Rome, Paris 1961.

ANDRZEJEWSKI R., Struktura antycznego listu polecajacego $w$ świetle zasad retoryki, RH 21 (1973) z. 3, 17-24.

Arnheim M.T.W., The Senatorial Aristocracy in the Later Roman Empire, Oxford 1972.

BrożeK M., Terencjusz, Wrocław 1960.

Combeaud B., Commentaire, w: D.M. Ausonii Burdigalensis, Opuscula omnia. Ausone de Bordeaux, Oeuvres complètes, texte établi, traduit et commenté par B. Combeaud, t. 1, Bordeaux 2010, 623-808.

CuRTius E.R., Literatura europejska i łacińskie średniowiecze, thum. A. Borowski, Kraków 1997.

Cytowska M. - Szelest H., Literatura rzymska. Okres cesarstwa. Autorzy chrześcijańscy, Warszawa 1994.

Cytowska M., Paulin z Noli uczeń Auzoniusza, „Meander” 49 (1994) 33-42.

ÉtIEnNe R., Ausone et l'Espagne, w: Mélanges d'archéologie, d'épigrahie et d'histoire oferts a Jérôme Carcopino, éd. J. Heurgon - G. Picard, Paris 1966, 319-332.

ÉtIENne R., Bordeaux antique, Bordeaux 1962.

Frend W.H.C., Paulinus of Nola and the Last Century of the Western Empire, JRS 59 (1969) 1-11.

GARZYA A., L'epistolografia letteraria tardoantica, w: tenże, Il mandarino e il quotidiano. Saggi nella letteratura tardoantica e bizantina, Napoli 1983, 347-365.

ГАСпаров М., Авсоний и его время, w: Авсоний, Стихотворения, ред. М. Гаспаров, Москва 1993, 251-272.

ГАСПАРов М., Примечания, w: Авсоний, Стихотворения, ред. М. Гаспаров, Москва 1993, 278-348.

Green R.P.H., Ausonius ',Fasti” and „Caesares” revisited, CQ 49 (1999) 573-578.

GreEn R.P.H., Commentary, w: The Works of Ausonius, edited with introduction and commentary by R.P.H. Green, Oxford 1991, 233-663.

GreEn R.P.H., The Correspondence of Ausonius, AC 49 (1980) 191-211.

Grimal P., Słownik mitologii greckiej i rzymskiej, tłum. M. Bronarska i inni, Wrocław 2008.

Kокоszко M., Ryby i ich znaczenie w życiu codziennym ludzi późnego antyku i wczesnego Bizancjum (III-VII w.), Łódź 2005.

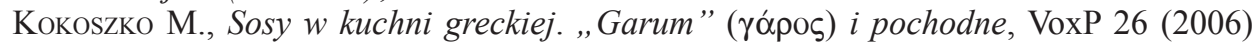
t. $49,289-298$.

KRYNICKA T., „Maturam frugem flore manente ferens”. Pochwała starości w poezjach Auzoniusza, VoxP 31 (2011) t. 56, 169-183. 
Krynicka T., Decymus Magnus Auzoniusz w świetle własnych utworów, Pelplin 2014.

KuMANIECKi K., Cyceron i jego współcześni, Warszawa 1959.

Lewandowski I., Historiografia rzymska, Poznań 2007.

Lomas Salmonte F.J., „, Secessus in villam”: la alternativa pagana al ascetismo cristiano en el círculo de Ausonio, „Antigüedad Cristiana” 8 (1990) 273-286.

Lorenzo Di E., Ausonio. Saggio su alcune componenti stilistiche, Napoli 1980.

MaŁunowiczówna L., Wstęp, w: Antologia listu starochrześcijańskiego, t. 1: Listy z dziedziny kierownictwa duchowego, Lublin 1978, 7-63.

Mondin L., Commento, w: Decimo Magno Ausonio, Epistole, introduzione, testo critico e commento a cura di L. Mondin, Venezia 1995, 59-289.

NARdo D., Ausonio e Orazio, „Paideia” 45 (1990) 321-336.

PaŁucki J., Epistolografia Paulina z Noli (355-430). Adresaci oraz okoliczności powstawania listów, w: Fructus Spiritus est Caritas. Księga jubileuszowa ofiarowana ks. prof. F. Draczkowskiemu, red. M. Wysocki, Lublin 2011, 305-314.

PaŁUCKI J., Świeccy adresaci listów Paulina z Noli, VoxP 22 (2002) t. 42-43, 253-260.

Pastorino A., Introduzione, w: Opere di Decimo Magno Ausonio, a cura di A. Pastorino, Torino 1971, 11-121.

Posani R.M., Reminiscenze di poeti latini nella „,Mosella” di Ausonio, „Studi Italiani di Filologia Classica" 34 (1962) 31-69.

SAwicka J., Feniks. Chrześcijańska interpretacja mitu u Laktancjusza, Warszawa 2000.

Sivan H., Ausonius of Bordeaux. Genesis of a Gallic aristocracy, London 1993.

STANKIEWICz L., Ilustrowany słownik mitologii greckiej i rzymskiej, Wrocław 2008.

StRZELECKi W., Zarys metryki łacińskiej, w: Metryka grecka i łacińska, red. W. Strzelecki - M. Dłuska, Wrocław 1959, 72-139.

Styka J., Sydoniusz Apollinaris i kultura literacka w Galii V wieku, Kraków 2008.

Swoboda A., Przyjaźń i konflikt Auzoniusza i Paulina z Noli w świetle korespondencji, „Eos” 83 (1995) 307-321.

The Prosopography of the Later Roman Empire, t. 1: A.D. 260-395, ed. A.H.M. Jones J.R. Martindale, Cambridge 1971.

Trout D., Paulinus of Nola. Life, Letters and Poems, Berkeley 1999.

Wasyl A.M., Rzymski list poetycki. Próba opisania gatunku, Kraków 2002.

WINNICZuK L., Ludzie, zwyczaje i obyczaje starożytnej Grecji i Rzymu, Warszawa 2006.

Winniczuk L., Pliniusz Młodszy w świetle swoich mów i listów, Warszawa 1987.

Witke C., ,, Numen Litterarum”. The Old and the New in Latin Poetry from Constatntine to Gregory the Great, Leiden 1971.

ŻMUDZIŃSKI M., Kilka słów o zbytku - spożyciu kosztownych przysmaków w rzymskich prowincjach $w$ dobie Cesarstwa, w: Zbytek i ubóstwo w starożytności i średniowieczu, red. L. Kostuch - K. Ryszewska, Kielce 2010, 245-251. 
